\title{
SURVEI MOTIVASI SISWA DALAM MENGIKUTI KEGIATAN EKSTRAKURIKULER FUTSAL DI SMAN 3 PALOPO
}

\author{
Rachmat Hidayat $^{1 \text { ) }}$, A.Heri Riswanto ${ }^{2)}$ \\ ${ }^{1}$ Universitas Muhammadiyah Palopo \\ ${ }^{2}$ Universitas Muhammadiyah Palopo \\ e-mail: rachmathidayat1405@gmail.com ${ }^{1}$, andiheryriswanto@gmail.com ${ }^{2}$
}

\begin{abstract}
Abstrak
Penelitian ini bertujuan untuk mengetahui seberapa besar Motivasi siswa dalam mengikuti kegiatan ekstrakurikuler futsal di SMAN 3 Palopo. Penelitian ini adalah penelitian deskriptif menggunakan metode survei, dengan teknik pengambilan data memakai instrumen berupa kuesioner yang berbentuk angket. Populasi pada penelitian ini adalah seluruh siswa yang mengikuti kegiatan ekstrakurikuler futsal di SMAN 3 Palopo sebanyak 30 siswa. Sampel adalah siswa yang mengikuti ekstrakurikuler futsal di SMAN 3 Palopo sebanyak 30 siswa, maka seluruh siswa dijadikan sampel pada penelitian ini. Teknik yang digunakan dalam pengambilan sampel adalah sampling purposive yaitu teknik pengambilan sampel dengan pertimbangan peneliti sendiri sehingga dapat mewakili populasi. Teknik analisis data menggunakan teknik analisis deskriptif kuantitatif yang dituangkan dalam bentuk persentase. Hasil penelitian motivasi siswa SMAN 3 Palopo dalam mengikuti kegiatan ekstrakurikuler futsal, sebagian besar berada dalam kategori sedang sebesar $53,3 \%$.
\end{abstract}

Kata Kunci : Motivasi, Ekstrakurikuler, Futsal

\begin{abstract}
This research is conducted to discover The motivation of the students in joining the Futsal Activity as an extracurriculer in SMAN 3 Palopo.This research was using descriptive with survey methoid, the instrument in this research was questionnaire. The Population was the whole Students of SMAN 3 Palopo who join the Futsal activity, There were 30 Students. The sample were the Students Who join the Futsal activity. Thus, all of the students were the sample in this research. And this reserach used purposive sampling by the consideration of the researcher in order to represent the population. Data analysis was Descriptive Quantitative in the form of percentage.The result of the motivation reserach in SMAN 3 Palopo in following the Futsal Activity as an extracurriculer, most of them are in medium category which is 53,3\%.
\end{abstract}

Keywords: Motivation, Extracurriculer, Futsal 


\section{Pendahuluan}

Pendidikan jasmani sebagai integral dari sitem pendidikan nasional yang orientasinya sangat jelas dalam tujuan pendidikan nasional yang ingin dicapai yaitui jasmani dan rohani. Pendidikan jasmani olahraga dan kesehatan telah menjadi salah satu pelajaran yang dimasukkan dalam kurikulum pendidikan yang dilaksanakan disemua pendidikan termasuk pada siswa sekolah menengah atas (SMA). Salah satu cabang olahraga yang dapat meningkatkan kebugaran jasmani dan juga merupakan olahraga yang paling dimotivasi para siswa yakni cabang olahraga futsal.

Futsal adalah permainan bola yang dimainkan oleh dua tim yang masingmasing berangotakan lima orang. Untuk dapat bermain futsal dengan baik seorang pemain harus dibekali dengan skill atau teknik dasar yang baik, tidak hanya sekedar bisa shooting bola tapi juga diperlukan keahlian dalam penguasai atau mengontrol bola. Pemain harus merasakan bahwa bola adalah bagian dari dirinya. Pemain yang memiliki skill atau teknik dasar yang ada beberapa macam teknik dasar yang harus dimiliki seorang pemain futsal yaitu: Passing, control, dribbling dan shooting.

Motivasi dapat dipandang sesuatu yang kompleks. Motivasi dikatakan sebagai serangkaian usaha untuk menyediakan kondisi-kondisi tertentu, sehingga seseorang mau dan ingin melakukan sesuatu, dan bila ia tidak suka maka akan berusaha untuk meniadakan atau mengelakan perasaan tidak suka itu. Jadi motivasi dapat dirangsang oleh aktor dari luar tetapi motivasi itu tumbuh dari dalam diri seseorang. Dalam kegiatan belajar, motivasi dapat dikatakan sebagai daya penggerak dalam diri siswa yang menimbulkan kegiatan belajar, yang menjamin kelangsungan dari kegiatan belajar dan yang memberikan arah pada kegiatan belajar, sehingga tujuan yang dikehendaki oleh subyek belajar itu dapat tercapai. Motivasi akan membangkitkan semangat dalam belajar. Apabila morivasi siswa dalam belajar tinggi, maka hasil belajarnya akan optimal dan sebaliknya jika motivasi belajar siswa rendah, maka hasil belajar akan menjadi kurang maksimal.

Kegiatan ekstrakurikuler merupakan kesempatan bagi anak untuk memenuhi motivasi dan bakatnya masing-masing. Maka bisa dikatakan tujuan dari ekstrakurikuler di sekolah adalah untuk penyaluran bakat dan prestasi serta sebagai kegiatan yang dapat mengurangi waktu anak untuk melakukan hal-hal yang negatif. Jadi selain sebagai olahraga pendidikan, futsal juga bisa disebut sebagai olahraga prestasi. Tidak jarang bahwa prestasi dari futsal di sekolah dapat membawa nama baik sekolah tersebut. Akan tetapi tidak mudah bagi sekolah untuk membuat prestasi futsal. Antara lain dengan cara mengadakan kegiatan ekstrakurikuler di sekolah.

Kegiatan ekstrakurikuler yang terdapat di SMAN 3 Palopo sekarang diharapkan siswa dapat meningkatkan prestasinya dibidang olahraga dan dengan adanya sarana dan prasarana yang dimiliki SMAN 3 Palopo, siswa menjadi lebih bermotivasi dan termotivasi dalam mengembangkan bakatnya dibidang olahraga, selain mempunyai kemampuan akademis, kemampuan di bidang olahraga juga tak kalah hebatnya. Dalam kegiatan ekstrakurikuler futsal di SMAN 3 Palopo biasanya pelatih atau guru olahraga menghendaki tiap siswa atau peserta berusaha untuk meningkatkan prestasi. Namun dalam kenyataaan tidak semua siswa atau peserta memiliki keinginan dan motivasi untuk berprestasi. Motivasi mereka sangat bervariasi, didorong kebutuhan yang dirasakan. Kesenjangan ini yang menimbulkan permasalahan dalam proses berlatih melatih olahraga pada umumnya, cabang olahraga futsal pada khususnya.

Berdasarkan permasalahan diatas maka penulis tertarik untuk melakukan 
penelitian tentang "Survei Motivasi Siswa dalam Mengikuti Kegiatan Ekstrakurikuler Futsal di SMAN 3 Palopo".

\section{Motivasi}

Menurut Dimyati (2013:86) "Motivasi merupakan kekuatan mental individu". Oleh sebab itu motivasi merupakan bagian yang sangat penting dalam suatu lembaga atau diri seseorang. Macam-macam motivasi adalah sebagai berikut:

1. Motivasi Intrinsik

Motivasi intrinsik adalah motif-motif yang menjadi aktif atau berfungsi akan tetapi tidak perlu rangsangan dari luar, karena dari dalam setiap individu sudah ada dorongan untuk melakukan sesuatu. Menurut Sardiman (2014:89), motivasi instrinsik adalah motif - motif yang menjadi aktif atau berfungsinya tidak perlu di rangsang dari luar, karena dalam diri setiap individu sudah ada dorongan untuk melakukan sesuatu. Misalnya: menguasai keterampilan dalam bermain futsal, mendapatkan pengetahuan olahraga dalam permainan futsal, mengembangkan sikap untuk dapat berhasil, ingin diterima orang lain, menyenangi olahraga futsal.

2. Motivasi Ekstrinsik

Menurut Sardiman (2014:89), Motivasi ekstrinsik adalah motif - motif yang aktif dan berfungsinya karena adanya perangsang dari luar. Menurut Winkel dalam Nyayu Khodijah (2014:152), motivasi ekstrinsik ini tetap diperlukan di sekolah, sebab pengajaran di sekolah tidak semuanya menarik motivasi siswa atau sesuai dengan kebutuhan siswa. Motivasi ekstrinsik ialah motivasi yang berasal dari luar diri seseorang itu sendiri. Misalnya: penghargaanpujian dan hukuman, teman, guru olahraga, fasilitas sekolah, lingkungan sekitar.

\section{Kegiatan Ekstrakurikuler}

Kegiatan ekstrakurikuler adalah kegiatan di luar jam pelajaran sekolah biasa, yang dilakukan di sekolah atau di luar sekolah dengan tujuan untuk memperluas pengetahuan siswa, mengenai hubungan antar mata pelajaran, menyalurkan bakat dan motivasi, serta melengkapi pembinaan manusia seutuhnya.

Menurut Depdiknas (2007:3)

Ekstrakurikuler juga diartikan sebagai kegiatan yang diselenggarakan di luar jam pelajaran yang tercantum dalam susunan program sesuai dengan keadaan dan kebutuhan sekolah berupa kegiatan pengembangan kepribadian, pengayaan dan perbaikan yang berkaitan dengan program kurikuler. Kegiatan-kegiatan untuk memantapkan kepribadian seperti palang merah remaja, olahraga, kepramukaan, usaha kesehatan sekolah, kesenian dan kegiatan lainnya.

Permainan Futsal

Futsal adalah permainan bola yang dimainkan oleh dua tim, yang masingmasing beranggotakan lima orang. Tujuanya adalah memasukkan bola ke gawang lawan, dengan memanipulasi bola dengan kaki. Untuk menjadi pemain futsal yang baik, kita harus mempelajari teknik bermain futsal yang benar. Menurut Timo Scheunemann (2013:10)" Saat bermain futsal, pemain dituntut untuk banyak bergerak maju mundur, kekiri kekanan sengan begitu cepat.

Menurut Giri Wijoyo (2012:315) Keterampilan teknik yang dimaksud disini ialah kemampuan melakukan gerakangerakan pada suatu cabang olahraga dari mulai gerak keterampilan yang paling sederhana sampai gerak keteranpilan yang sulit, termasuk gerak tipu yang menjadi cabang olahraga itu". Dari beberapa pendapat diatas dapat disimpulkan bahwa keterampilan teknik merupakan hasil dari proses belajar gerak yang diproses dan dikembangkan kedalam suatu pola gerak terkoordinasi dan terpadu untuk mendapatkan penampilan yang maksimal.

Adapun keterampilan bermain futsal yang harus dikuasai antara lain sebagai berikut menggiring bola, mengoper dan menerima bola, menmbak bola,

\section{Profil Kegiatan Ekstrakurikuler SMAN 3 Palopo}

SMAN 3 Palopo sebagai lembaga pendidikan, menyadari pentingnya hal tersebut. Salah satu aktualisasinya adalah 
melalui kegiatan ekstrakurikuler (ekskul) dengan tujuan pengembangan bakat, motivasi, serta kreativitas yang dimiliki siswa. Salah satu kelebihan sekolahsekolah di lingkungan SMAN 3 Palopo adalah jumlah kegiatan ekskulnya. Selain sebagai penunjang materi kurikulum, kegiatan tersebut juga bertujuan untuk menyalurkan bakat dan kreativitas siswa, sekaligus untuk mengisi waktu luang mereka.

\section{BAHAN DAN METODE/METODOLOGI}

Penjelesan singkat mengenai dimana lokasi penelitian,kapan penelitian dilaksanakan, bahan atau intrumen apa yang digunakan dan metode apa yang digunakan untuk melakukan penelitian atau memecahkan masalah.

Dalam penelitian ini yang menjadi variabel adalah motivasi siswa dalam mengikuti kegiatan ekstrakurikuler futsal di SMAN 3 Palopo. Dalam penelitian ini menggunakan metode survei yaitu penelitian yang mengambil sampel dari suatu populasi dan menggunakan kuesioner sebagai alat pengumpulan data yang pokok

Adapun populasi dalam peneliitian ini adalah seluruh siswa laki laki yang mengikuti kegiatan ekstrakurikuler futsal di SMAN 3 Palopo sebanyak 30 siswa. Berdasarkan dari pendapat diatas berhubung siswa laki laki yang mengikuti ekstrakurikuler futsal di SMAN 3 Palopo sebanyak 30 siswa, maka seluruh siswa akan dijadikan sampel pada penelitian ini.

Untuk mengumpulkan data yang diperlukan dalam penelitian ini penulis menggunakan survei dengan sistem angket atau kuesioner. Pada penelitian survei, penggunaan angket merupakan hal yang pokok untuk pengumpulan data. Hasil kuesioner tersebut akan terjelma dalam angka-angka, tabel-tabel, analisis statistik dan uraian serta kesimpulan hasil penelitian. Teknik analisis data yang digunakan dalam penelitian ini adalah analisis deskriptif kuantitatif dengan presentase.

\section{HASIL DAN PEMbahasan}

Pemaparan hasil secara runut dan komprehensif yang mengarah pada pemecahan masalah yang dikaji/teliti.

Tabel 1. Hasil analisis deskriptif data penelitian motivasi

\begin{tabular}{|l|c|c|c|}
\hline & $\begin{array}{c}\text { Motivas } \\
\mathrm{i}\end{array}$ & Intrinsik & Ekstrinsik \\
\hline Mean & 119.03 & 59.17 & 59.87 \\
\hline Median & 116.50 & 57.50 & 59.00 \\
\hline Mode & 114 & 56 & 57 \\
\hline Std.Deviasi & 11.482 & 6.176 & 5.425 \\
\hline Min & 85 & 41 & 44 \\
\hline Max & 139 & 70 & 69 \\
\hline
\end{tabular}

Dari tabel 1 di atas yang merupakan gambaran data motivasi. Dapat dikemukakan sebagi berikut:

a. Hasil analisis deskriptif pada data motivasi siswa yang mengikuti kegiatan ekstrakurikuler futsal, diperoleh nilai mean sebesar 119.03, nilai median sebesar 116.50, nilai mode sebesar 114 , nilai std.deviasi sebesar 11.482 , nilai min sebesar 85 dan nilai max sebesar 139.

b. Hasil analisis deskriptif pada data motivasi intrinsik, diperoleh nilai mean sebesar 59.17, nilai median sebesar 57.50, nilai mode sebesar 56, nilai std.deviasi sebesar 6.176 , nilai min sebesar 41 dan nilai max sebesar 70 .

c. Hasil analisis deskriptif pada data motivasi ekstrinsik, diperoleh nilai mean sebesar 59.87, nilai median sebesar 59.00, nilai mode sebesar 57, nilai std.deviasi sebesar 5.425, nilai min sebesar 44 dan nilai max sebesar 69.

\section{Hasil Uji Kualitas Data}

Tabel 2. Hasil uji validitas data

\begin{tabular}{|c|c|c|c|}
\hline Item & $\begin{array}{c}\mathrm{r} \\
\text { Hitung }\end{array}$ & $\mathrm{t}$ tabel & Ket. \\
\hline Item 1 & 0,766 & 0,349 & Valid \\
\hline Item 2 & 0,872 & 0,349 & Valid \\
\hline Item 3 & 0,691 & 0,349 & Valid \\
\hline Item 4 & 0,373 & 0,349 & Valid \\
\hline
\end{tabular}




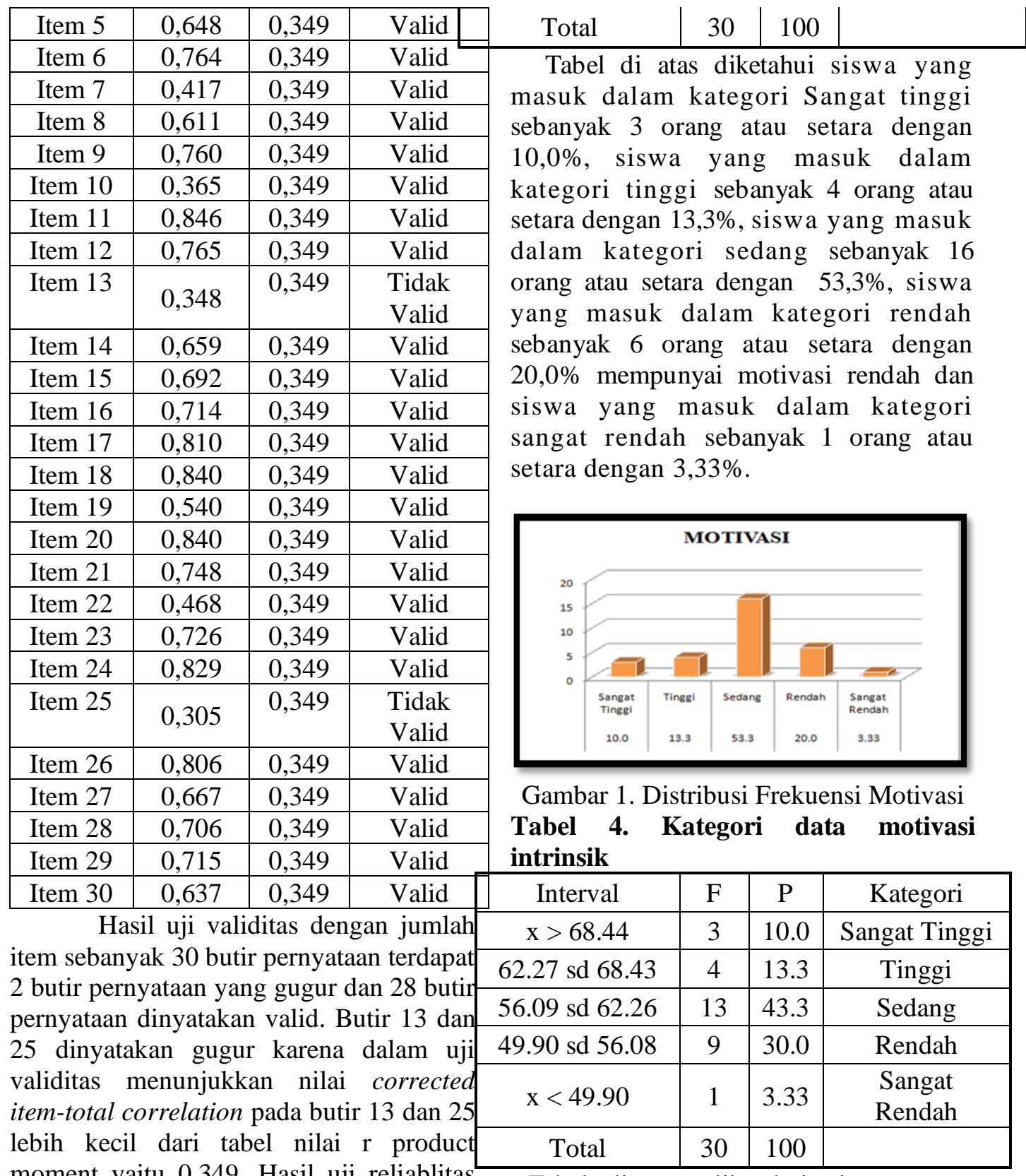
moment yaitu 0,349 . Hasil uji reliablitas dengan melihat nilai cronbach's alpha dari variabel motivasi siswa dalam mengikuti ekstrakurikuler futsal di atas 0,05 yaitu 0,756 dapat dikatakan reliabel atau handal.

Tabel 3. Kategori data motivasi siswa

Tabel di atas diketahui siswa yang masuk dalam kategori sangat tinggi sebanyak 3 orang atau setara dengan $10,0 \%$, siswa yang masuk dalam kategori tinggi sebanyak 4 orang atau setara dengan $13,3 \%$, siswa yang masuk

\begin{tabular}{|c|c|c|c|}
\hline Interval & $\mathrm{F}$ & $\mathrm{P}$ & Kategori dalam kategori sedang sebanyak 13 \\
\hline$x>136.26$ & 3 & 10.0 & Sangat Tinggionang atau setara dengan $43,3 \%$, siswa \\
\hline $124.78 \mathrm{sd} 136.25$ & 4 & 13.3 & yang masuk dalam kategori rendah \\
\hline $113.30 \mathrm{sd} 124.77$ & 16 & 53.3 & Sedang \\
\hline $101.81 \mathrm{sd} 113.29$ & 6 & 20.0 & s) swa yang masuk dalam kategori \\
\hline$x<101.81$ & 1 & 3.33 & $\begin{array}{l}\text { s angat rendah sebanyak } 1 \text { orang atau } \\
\text { setara dengan } 3,33 \% \text {. }\end{array}$ \\
\hline
\end{tabular}




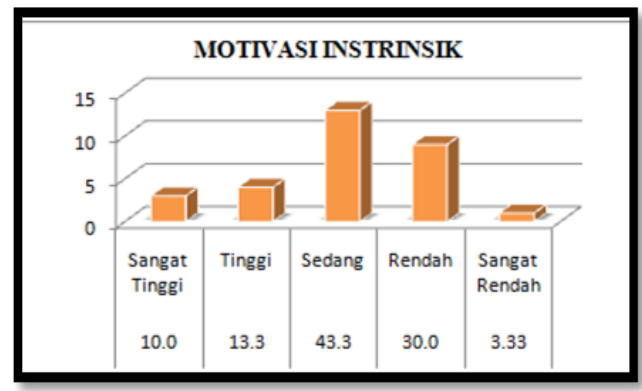

Gambar 2. Distribusi Frekuensi Motivasi Intrinsik

Tabel 5. Kategori data motivasi ekstrinsik

\begin{tabular}{|c|c|c|c|}
\hline Interval & $\mathrm{F}$ & $\mathrm{P}$ & Kategori \\
\hline $\mathrm{x}>68.02$ & 3 & 10.0 & Sangat Tinggi \\
\hline 62.59 sd 68.01 & 4 & 13.3 & Tinggi \\
\hline 57.17 sd 62.58 & 13 & 43.3 & Sedang \\
\hline 51.73 sd 57.16 & 9 & 30.0 & Rendah \\
\hline $\mathrm{x}<51.73$ & 1 & 3.33 & Sangat Rendah \\
\hline Total & 30 & 100 & \\
\hline
\end{tabular}

Tabel di atas diketahui siswa

yang masuk dalam kategori sangat tinggi sebanyak 3 orang atau setara dengan $10,0 \%$, siswa yang masuk dalam kategori tinggi sebanyak 4 orang atau setara dengan $13,3 \%$, siswa yang masuk dalam kategori sedang sebanyak 13 orang atau setara dengan $43,3 \%$,siswa yang masuk dalam kategori rendah sebanyak 9 orang atau setara dengan $30,0 \%$ dan siswa yang masuk dalam kategori sangat rendah sebanyak 1 orang atau setara dengan $3,33 \%$.

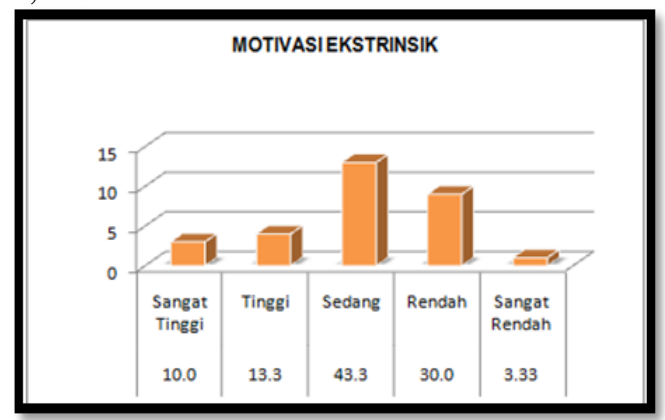

Gambar 3. Distribusi Frekuensi Motivasi Intrinsik

Penelitian ini bertujuan untuk mengetahui seberapa besar motivasi siswa dalam mengikuti kegiatan ekstrakurikuler futsal di SMAN 3 Palopo. Hasil analisis deskriptif kuantitatif menunjukan bahwa motivasi siswa dalam mengikuti kegiatan ekstrakurikuler futsal di SMAN 3 Palopo dalam kategori sedang sebesar 53,3\%. Hasil ini menunjukan bahwa kegiatan ekstrakurikuler futsal di SMAN 3 Palopo belum ada perhatian yang kuat dari siswa untuk aktif mengikuti kegiatan ekstrakurikuler futsal.

Faktor instrinsik adalah yang berasal dari dalam individu itu sendiri faktor intrinsik yaitu yang berhubungan dengan motivasi itu sendiri dan motivasi fang lebih mendasar. Hasil analisis menunjukkan motivasi intrinsik siswa dalam kategori sedang sebesar 43,3\%. Faktor ekstrinsik yaitu yang ditunjukan lengan adanya emosi senang yang perhubungan dengan tujuan dari aktivitas ertentu. Hasil analisis menunjukan motivasi ekstrinsik siswa dalam kategori hedang sebesar 43,3\%.

\section{KESIMPULAN DAN SARAN}

Kesimpulan ditulis singkat,jelas dan sistematik sesuai runtutan paparan dalam Hasil dan Pembahasan dan menjawab masalah yang diteliti/dikaji. Sementara, sasaran diberikan sesuai dengan apa yang menjadi masalah dalam penerapan metode dan hasil yang didapat.

\section{Kesimpulan}

Berdasarkan hasil analisis dan pembahasan, maka dapat diambil kesimpulan bahwa motivasi siswa dalam mengikuti kegiatan ekstrakurikuler futsal di SMAN 3 Palopo sebagian besar berada dalam kategori sedang sebesar $53,3 \%$.

\section{Saran}

1. Meningkatkan motivasi terhadap kegiatan ekstrakurikuler sepakbola, dan aktif mengikuti latihan sehingga akan dapat meningkatkan kebugaran jasmani, keterampilan dalam bermain sepakbola

2. Mengembangkan penelitian ini dengan melakukan penelitian pada populasi yang lebih besar dan dengan variabel yang lebih beragam sehingga penelitianakan 
lebih maksimal.

Daftar Pustaka

Arikunto, Suharsimi. 2002. Prosedur Penelitian Suatu pendekatan Praktek. Jakarta: Penerbit Rineka Cipta.

Depdiknas. 2007. Model Pengembangan Diri. Jakarta:P4TK Penjas dan BK.

Dimyanti dan Mudjiono. 2013. Belajar dan Pembelajaran. Jakarta: Rineka Cipta.

Halim Sahda. 2009. Hari Pintar Main

Futsal. Yogyakarta: Media Pressindo

Husdarta, S. J. 2010. Manajemen Pendidikan Jasmani. Bandung: Alfabeta.

Khodijah, Nyayu. 2014. Psikologi Pendidikan. Jakarta: PT Rajagrafindo Persada.

Noor, Juliansyah. 2012. Metodologi Penelitian. Jakarta: Kencana Prenada Media Group.

Nugraha.A.R. 2010. Mengenal Aneka Cabang Olahraga. Bekasi: Penerbit PT Cahaya Pustaka Raga.

Paturusi, Achmad. 2012. Managemen Pendidikan Jasmani dan Olahraga. Rineka Cipta, Jakarta.

Sardiman. 2004. Interaksi \& Motivasi Belajar Mengajar. Jakarta: PT Raja Grafindo Persada.

Schuneumann Timo. 2013. Futsal For

Winner (Taktik dan Variasi

Latihan Futsal). Malang: Dioma Anggota IKAPI.

Sudijono, Anas. 2010. Pengantar

Statistik Pendidikan. Jakarta:

Raja Grafindo Persada.

Sugiyono. 2014. Metode Penelitian Kuantitatif, Kualitatif, dan Kombinasi ( Mixed Methods ). Bandung : Alfabeta.
Wijoyo, Giri. 2013. Fisiologi dan Olahraga. Yogyakarta: Graha Ilmu. 